\title{
Effects of thermal-time artificial scarification on the germination dynamics of black locust (Robinia pseudoacacia L.) seeds
}

\author{
Szymon Jastrzębowski ${ }^{1} \cdot$ Joanna Ukalska $^{2} \cdot$ Władysław Kantorowicz ${ }^{1} \cdot$ \\ Marcin Klisz $^{1}$ - Tomasz Wojda ${ }^{1}$ Małgorzata Sułkowska ${ }^{1}$
}

Received: 21 November 2016/Revised: 23 March 2017/Accepted: 27 March 2017/Published online: 4 April 2017

(c) The Author(s) 2017. This article is an open access publication

\begin{abstract}
The aim of this study was to determine the efficiency of methods for the artificial scarification of black locust seeds based on the influence of the air and liquid nitrogen temperatures. Three populations were selected for the analyses: a managed tree stand, a selected seed stand and a seed orchard. Samples of 200 seeds $(4 \times 50)$ were randomly selected. Before scarification, the seeds were stored at $-70{ }^{\circ} \mathrm{C}$ for $24 \mathrm{~h}$. Nine different scarification treatments were evaluated. To calculate the germination capacity and the dynamics of germination, observations were made on days 3, 5, 7, 10 and 14 after treatment. For statistical analyses, we used repeated measures analysis of variance. The obtained results indicated that the highest scarification efficiency for black locust seeds occurred in the treatment in liquid nitrogen and in an air temperature range of $85-90{ }^{\circ} \mathrm{C}$. The provenance of seeds had a significant effect on the dynamics of germination. Thermal methods and the use of liquid nitrogen can be alternatives to the labour intensive methods of cutting the seeds or using measures that require specialised equipment.
\end{abstract}

Keywords Fabaceae $\cdot$ Dormancy $\cdot$ Germination dynamics $\cdot$ Repeated measures

Communicated by Jarmo Holopainen.

Szymon Jastrzębowski

s.jastrzebowski@ibles.waw.pl

1 Department of Silviculture and Forest Tree Genetics, Forest Research Institute, 3 Braci Leśnej Str., 05-090 Raszyn, Poland

2 Biometry Division, Department of Econometrics and Statistics, Faculty of Applied Informatics and Mathematics, Warsaw University of Life Sciences, Nowoursynowska 159, 02-776 Warsaw, Poland

\section{Introduction}

The genus Robinia includes 19 botanical taxa, with eight classified as species and the others as natural hybrids or varieties (Rédei 2013; Zajączkowski 2013). The current natural range is North America, although in the Oligocene and Miocene, certain species of the genus were also found in central Europe (Pacyniak 2003).

Black locust is acclimated to Poland (Pacyniak 1981) and is selected for use in midfield forests and in the production of wood raw material on plantations of fastgrowing trees (Węgorek and Kraszkiewicz 2005; Zajączkowski 2007; Zajączkowski and Wojda 2012). Currently, black locust occurs most frequently in the fresh mixed broadleaved and fresh mixed coniferous forest sites in Poland (43 and 32\%, respectively). On land under state forestry management, black locust is found in 88,500 forest subcompartments that cover a total of 273,000 ha (Wojda et al. 2015). Nevertheless, because of the alien origin and tendency for expansive growth that characterise the species, black locust is a potential threat to native phytocoenoses (Danielewicz and Wiatrowska 2012; Gazda 2012; Kowalewski 2013). Despite the potential threat, black locust is subject to the Program zachowania leśnych zasobów genowych i hodowli selekcyjnej drzew leśnych $w$ Polsce (Program for the conservation of forest genetic resources and tree breeding in Poland for the years 2011-2035), which anticipates a further increase in the size of the seed base for the species (Program 2011). Studies are also being conducted on the biological and environmental determinants to optimise the biomass production of black locust wood plantations for industrial and energy uses (Kraszkiewicz 2013).

Black locust reproduces sexually and asexually by underground runners (Cierjacks et al. 2013). The first 
flowering occurs at the age of 5-6 years, with the flowers pollinated by insects, primarily honeybees. The fruit is a pod that matures in autumn. A pod contains 4-10 dark brown seeds without endosperm that are 4-6 $\mathrm{mm}$ in length. Every 1 or 2 years, a good crop of seeds is produced (Olson and Karrfalt 2008). Seeds can be stored for 10 years or more at a temperature of $0-5{ }^{\circ} \mathrm{C}$ (USDA Forest Service 1974; DeGomez and Wagner 2001). The soil seed bank of black locust can be as high as 2000 seeds per $\mathrm{m}^{2}$, with germination that may occur over several decades (Cseresnyés and Csontos 2012).

The commercial use of seeds requires pre-treatment before sowing to break exogenous dormancy due to the structure of the seed coat, which is impermeable to water and gases (Nikolaeva et al. 1985; Olson and Karrfalt 2008). Moreover, the imbibition and course of processes that are essential for germination are inhibited in the dormancy stage (Lewak 2002). The impermeability of the seed coat, understood as physical dormancy, is a very important ecological mechanism to ensure that germination occurs only in conditions favourable for seedling growth (Bewley 1997; Borkowska 2004; Falińska 2002; Baskin and Baskin 2009; Willis et al. 2014). However, this phenomenon is undesirable when seeds are intended for commercial use in forest practise (Mondoni et al. 2013). To break the dormancy of seeds, the seed coat must be damaged. Under natural conditions, the seed coat can be damaged by either low (frosts) or high temperatures (fires) or by the activity of the soil microflora (Jackson and Strait 1987; Lewak 2002).

Three methods are currently used to scarify black locust seeds at an economic scale, i.e., mechanical, chemical and thermal (Chapman 1936; McKeever 1937; Hanna 1983; DeGomez and Wagner 2001; Baskin 2003; Mirzaei et al. 2013). This study proposes a new method for artificial scarifying black locust seeds by using very low temperatures (liquid nitrogen) or high temperatures (incubator).

\section{Materials and methods}

\section{Seed collection and initial preparation}

Mature, dry seeds were collected in autumn 2013 from the forest districts Krosno and Mieszkowice (Western Poland; Table 1). The choice of location of objects was associated with a significant share of black locust in the stands growing in this part of Poland. Seeds represented a seed orchard (SO), a selected seed stand (SSS) and a managed tree stand (MTS). Selected objects were different, in terms of their forest management type and the level of selection form-from the lowest (MTS) to the highest (SO). Seeds were mechanically husked from the pods. The empty and immature seeds were separated with the pod remains to obtain pure seeds. Seeds were weighed to an accuracy of $0.01 \mathrm{~g}$ on an analytical balance.

\section{Seed coat impermeability}

Unscarified seeds were used to determine percentage of the seeds germinated without any treatments. To determine the potential germination of samples, part of the seed coat was manually damaged by a scalpel incision, and the seeds treated with this mechanical scarification were the control treatment (MS). To determine percentage of seeds able to germinate without any treatment in each provenances (MTS, SSS, SO), we placed fresh seeds on filter paper in Jacobsen apparatus. Observations were made by 14 days. As in case of treatment seeds, we counted germinated seeds in 3, 5, 7, 10 and 14 days after beginning of the test (ISTA 2013).

\section{Scarification methods}

Effect of eight scarification methods on germination of black locust was tested: mechanical scarification with a scalpel (MS), liquid nitrogen (LN) and air temperature (T) at 85,90 and $95{ }^{\circ} \mathrm{C}$ with two variants of time $(t)$ of 10 and $20 \mathrm{~min}$ (T85_t10, T85_t20, T90_t10, T90_t20, T95_t10 and T95_t20). Four replicates of 50 seeds selected randomly per populations were used in each treatment (3 populations; 9 variants -8 scarification methods and 1 variants with non-scarification seeds; 4 replicates -in total 5400 assessed seeds). Before treating them, the seeds were put in a freezer at $-70{ }^{\circ} \mathrm{C}$ for $24 \mathrm{~h}$ (seeds treated by thermal-time scarification methods). In the liquid nitrogen treatment, the seeds were not previously frozen. The scarified by thermal scarification-time methods seeds then were placed in the incubator depending on the time-temperature variant. A constant temperature was achieved using a Eurotherm 91e incubator (Carbolite-company).
Table 1 Location of seed collection sites in western Poland

\begin{tabular}{lllll}
\hline Type & FD & FR & Coordinates & Area (ha) \\
\hline SSS & Krosno & Radomicko & N52 $08^{\prime} 24.1 ;$ E14 $55^{\prime} 14.3$ & 3.18 \\
SO & Krosno & Gęstowice & N52 $09^{\prime} 49.5 ;$ E14 $14^{\circ} 54^{\prime} 52.4$ & 5.65 \\
MTS & Mieszkowice & Rudnica & N52 $52^{\circ} 31.5 ;$ E14 $11^{\circ} 40.7$ & 1.31 \\
\hline
\end{tabular}

SSS selected seed stand, $S O$ seed orchard, MTS managed tree stand, FD forest district, $F R$ forest range 
The seeds scarified in LN method were kept in liquid nitrogen for $10 \mathrm{~s}$.

\section{Germination test}

After thermal and mechanical scarification, the seeds were tested for germination at $24{ }^{\circ} \mathrm{C}$ on a Jacobsen's germination apparatus for 14 days, as suggested by Załęski (2000) and ISTA (2013). Observations were made on days 3, 5, 7 , 10 and 14 after treatment.

\section{Statistical analyses}

In order to determine whether the seed in each populations is able to germinate without scarification and to test whether there are significant differences among populations, the ANOVA (one way analysis of variance) was performed.

The final germination capacity was calculated using the following formula:

FGC $=\frac{N_{\mathrm{s}}}{N} 100 \%$

where $N_{\mathrm{s}}$ is the number of germinated seeds and $N$ is the number of total seeds.

Germination capacity among populations and scarification variants was analysed according to a fixed general linear model as it follows:

$\mathrm{GC}_{i j k}=\mu+P_{i}+M_{j}+P M_{i j}+e_{i j k}$,

where $\mathrm{GC}_{i j k}$ is the percentage of germinated seeds of the $i$ th provenance, under the $j$ th scarification, $\mu$ is the overall mean, $P_{i}$ is the $i$ th provenance effect, $M_{j}$ is the $j$ th scarification effect, $P M_{i j}$ is the provenance $\times$ treatment interaction effect, and $e_{i j k}$ is the experimental error.

The dynamics of germination capacity were observed throughout the experiment for each treatment adopted with respect to scarification and the provenance of the seeds. To determine the dynamics of germination capacity for the seed, i.e., the changes in the mean germination in time, depending on the scarification and the provenance of the seeds, we used a repeated measures analysis of variance, according to the following linear model:

$$
\begin{aligned}
\mathrm{GD}_{i j k l}= & \mu+P_{i}+M_{j}+T_{k}+P M_{i j}+P T_{i k}+M T_{j k} \\
& +P M T_{i j k}+e_{i j k l}
\end{aligned}
$$

where $\mathrm{GD}_{i j k l}$ is the percentage of germinated seeds of the $i$ th provenance, under the $j$ th scarification treatment and on the $k$ th day of the trial, $\mathrm{PT}_{i k}$ is the provenance $\times$ day of the trial interaction effect, $\mathrm{MT}_{j k}$ is the treatment $\times$ day of the trial interaction effect, $\mathrm{PMT}_{i j k}$ is the provenance $\times$ treatment $\times$ day of the trial interaction effect, and $e_{i j k l}$ is the experimental error; the other effects are the same as in model 2.

Percentage data used in all the above mentioned analysis of variance were transformed using Bliss's transformation (arc-sin transformation). Differences among the means were analysed by Tukey's honestly significant difference (HSD) tests. $p \leq 0.05$ was considered the significance threshold in this study. The analyses were carried out using the SAS 9.4 software (SAS Institute 2013), and MIXED procedure was followed (Littell et al. 1996).

\section{Results}

\section{Seed coat impermeability}

Significant differences were observed in germination capacity of unscarified seeds among provenances $(F=6.6$; $p=0.017)$. In MTS provenance, significantly more seeds germinated (15.5\%) than in the SSS (5.0\%)—Fig. 1.

\section{Final germination capacity}

Based on analysis of variance, significant differences were detected among the provenances $(P)$, thermal-time scarification methods $(M)$ and $P \times M$ interaction (Table 2). The MTS was characterised by the highest final percentage of germinated seeds (mean $\pm \mathrm{SD} ; 92.4 \% \pm 3.01$; Table 3 ), followed by the SSS $(87.4 \% \pm 8.63)$. While of the seeds harvested on the SO, only $77.7 \%( \pm 12.18)$ germinated, which was significantly less than the other provenances.

At the end of the test, the optimum results were obtained using the MS and LN methods (germination capacity 91.8 and $91.2 \%$, respectively, Table 3 ). Among the thermaltime scarification methods, the variants T85_t10 and T85_t20 were the most effective (germination capacity 89.2 and $89.8 \%$, respectively). For both time variants,

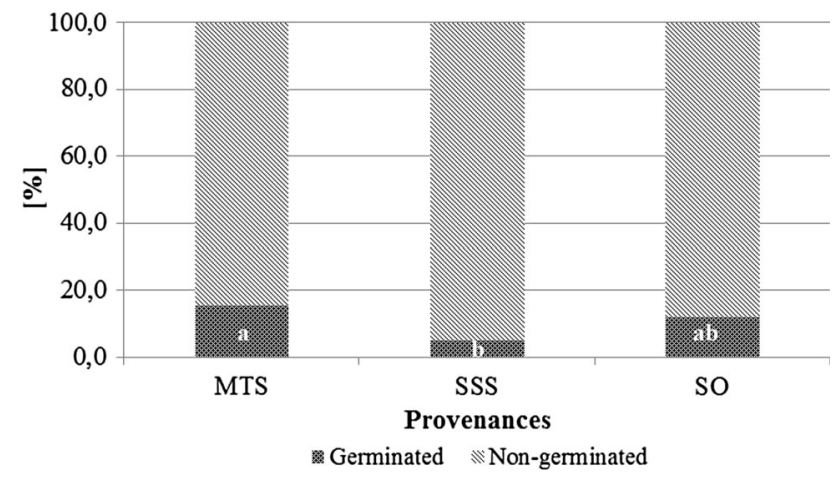

Fig. 1 Percentage of germinated and non-germinated seeds of black locust collected from three sites. MTS managed tree stand, SSS selected seed stand, $S O$ seed orchard. Means (germinated seeds) with the same lowercase letter are not significantly different at $p \leq 0.05$ 
$95{ }^{\circ} \mathrm{C}$ had a negative effect on the germination of black locust seeds, and maintaining this high temperature for 10 min resulted in a decrease in seed germination capacity to $79.8 \%$, with the decrease to $70.7 \%$ at $20 \mathrm{~min}$. The seeds scarified at $-195.8{ }^{\circ} \mathrm{C}(\mathrm{LN})$ were characterised by a very high germination capacity, regardless of the origin. However, at the end of test, the mean germination capacity of seeds scarified by LN method, which reached $91.2 \%$, did not differ significantly from the germination capacity of seeds treatment by MS and most of the thermal variants, except T95_t10 and T95_t20.

The significant decrease in germination capacity of seeds from the SSS and SO was also found after the treatment by air temperature of $95^{\circ} \mathrm{C}$ for 10 or $20 \mathrm{~min}$ when compared to seeds from the MTS. Seeds from MTS retained a high germination ability after the T95_t10 and T95_t20 treatments (Table 3).

\section{Germination dynamics of seeds}

Depending on the provenance of seeds and scarification treatment, the germination capacity was significantly affected by time duration of the thermal treatment

Table 2 ANOVA table for the final germination capacity

\begin{tabular}{lclrl}
\hline $\begin{array}{l}\text { Model } \\
\text { effect }\end{array}$ & Num DF & Denom DF & $F$ & $p$ \\
\hline$P$ & 2 & 72 & 54.85 & $<0.001$ \\
$M$ & 7 & 72 & 17.00 & $<0.001$ \\
$P \times M$ & 14 & 72 & 3.89 & $<0.001$ \\
\hline
\end{tabular}

$\mathrm{P}$, provenance; $\mathrm{M}$, scarification method; Num DF, numerator degrees of freedom; Denom DF, denominator degrees of freedom; $F$ test statistics; $p, p$ values (interactions $P \times T$ and $M \times T$, in both cases $p<0.001$ ). However, there were no significant differences in dynamics of germination of seeds from the different provenances, even when they were scarified using different methods (interaction $P \times M \times T, p=0.83$ ). The ANOVA results for 3rd model revealed the importance of the $(P)$ and $(M)$ effects and their interaction $M \times P$ (Table 4). However, due to the fact that in the 3rd model the results of variation in time (interaction $P \times T$ and $M \times T P \times M \times T$ ) for us were the most important the effects of $P, M, M \times P$ variation was not be further discussed.

On the third day of incubation, significantly poor germination of seeds from all temperature-time and $\mathrm{LN}$ variants was observed compared to the MS treatment (Fig. 2). However, LN variant had a higher germination than T85_t10, T90_t10, T95_t10 and T95_t20 variants though no significant differences were observed among treatments.

Table 4 ANOVA table for the dynamics of seed germination capacity

\begin{tabular}{lclrl}
\hline Model effect & Num DF & Denom DF & \multicolumn{1}{l}{$F$} & \multicolumn{1}{l}{$p$} \\
\hline$P$ & 2 & 360 & 440.87 & $<0.001$ \\
$M$ & 7 & 360 & 81.27 & $<0.001$ \\
$T$ & 4 & 360 & 617.71 & $<0.001$ \\
$M \times P$ & 14 & 360 & 16.96 & $<0.001$ \\
$P \times T$ & 8 & 360 & 13.03 & $<0.001$ \\
$M \times T$ & 28 & 360 & 4.36 & $<0.001$ \\
$P \times M \times T$ & 56 & 360 & 0.81 & 0.832
\end{tabular}

$P$ provenance, $M$ scarification method, $T$ time duration, Num DF numerator degrees of freedom, Denom $D F$ denominator degrees of freedom, $F$ test statistics, $p p$ values
Table 3 Final germination capacity (FGC) of black locust seeds for different scarification methods

\begin{tabular}{lllll}
\hline Scarification methods & \multicolumn{2}{l}{ FGC $(\%)$ mean \pm SD } & \multirow{2}{*}{$\begin{array}{l}\text { Total for scarification } \\
\text { methods }\end{array}$} \\
\cline { 2 - 4 } & MTS & SSS & SO & \\
\hline MS & $94.0 \pm 0.00^{\mathrm{ab}}$ & $94.5 \pm 4.12^{\mathrm{a}}$ & $87.0 \pm 8.41^{\mathrm{b}}$ & $91.8 \pm 4.19^{\mathrm{A}}$ \\
LN & $95.0 \pm 3.46^{\mathrm{a}}$ & $92.5 \pm 3.00^{\mathrm{ab}}$ & $86.0 \pm 1.63^{\mathrm{b}}$ & $91.2 \pm 4.65^{\mathrm{A}}$ \\
T85_t10 & $93.0 \pm 2.00^{\mathrm{a}}$ & $93.0 \pm 1.15^{\mathrm{a}}$ & $81.5 \pm 5.26^{\mathrm{b}}$ & $89.2 \pm 6.64^{\mathrm{A}}$ \\
T85_t20 & $94.0 \pm 3.27^{\mathrm{a}}$ & $88.0 \pm 2.83^{\mathrm{a}}$ & $87.5 \pm 5.97^{\mathrm{a}}$ & $89.8 \pm 3.62^{\mathrm{A}}$ \\
T90_t10 & $86.0 \pm 5.89^{\mathrm{ab}}$ & $93.5 \pm 4.73^{\mathrm{a}}$ & $77.5 \pm 10.38^{\mathrm{b}}$ & $85.7 \pm 8.01^{\mathrm{AB}}$ \\
T90_t20 & $94.5 \pm 1.91^{\mathrm{a}}$ & $88.5 \pm 4.43^{\mathrm{ab}}$ & $82.5 \pm 3.42^{\mathrm{b}}$ & $88.5 \pm 6.00^{\mathrm{A}}$ \\
T95_t10 & $92.5 \pm 1.91^{\mathrm{a}}$ & $80.0 \pm 4.32^{\mathrm{b}}$ & $67.0 \pm 6.83^{\mathrm{b}}$ & $79.8 \pm 12.75^{\mathrm{B}}$ \\
T95_t20 & $90.0 \pm 6.00^{\mathrm{a}}$ & $69.5 \pm 3.00^{\mathrm{b}}$ & $52.5 \pm 4.12^{\mathrm{c}}$ & $70.7 \pm 18.78^{\mathrm{C}}$ \\
Total for provenances & $92.4 \pm 3.01^{\mathrm{a}}$ & $87.4 \pm 8.63^{\mathrm{b}}$ & $77.7 \pm 12.18^{\mathrm{c}}$ & \\
\hline
\end{tabular}

Means with the same lowercase letter within a row or means with the same uppercase letter within a column are not significantly different at $p \leq 0.05$. SD standard deviation, MTS managed tree stand, SSS selected seed stand, $S O$ seed orchard, $M S$ mechanical scarification, $L N$ liquid nitrogen. T85_t10 $-85^{\circ} \mathrm{C}$ (air temperature) by $10 \mathrm{~min}, \mathrm{~T} 85 \_\mathrm{t} 20-85^{\circ} \mathrm{C}$ by $20 \mathrm{~min}, \mathrm{~T} 90 \_\mathrm{t} 10-90^{\circ} \mathrm{C}$ by $10 \mathrm{~min}, \mathrm{~T} 90 \_\mathrm{t} 20-90^{\circ} \mathrm{C}$ by $20 \mathrm{~min}$, T95_t $10-95{ }^{\circ} \mathrm{C}$ by $10 \mathrm{~min}, \mathrm{~T} 95 \_\mathrm{t} 20-95{ }^{\circ} \mathrm{C}$ by $20 \mathrm{~min}$ 


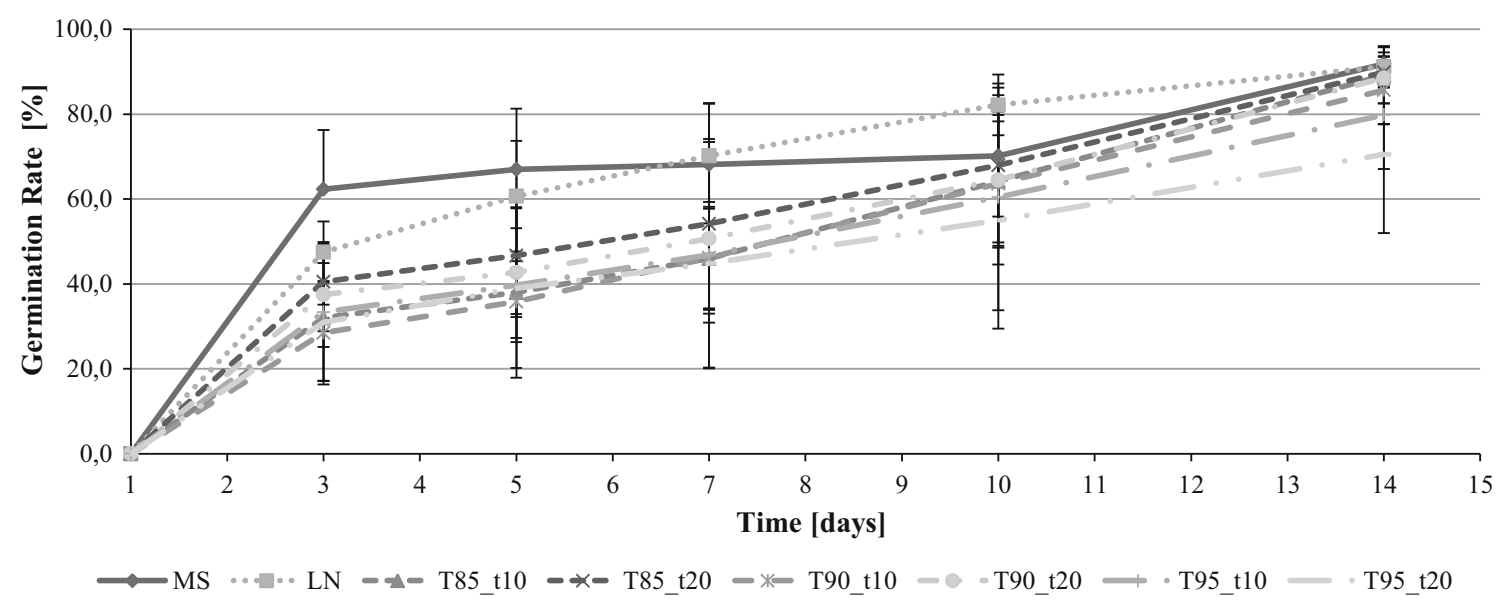

Fig. 2 Germination dynamics of seeds treated with different scarification methods. $M S$ mechanical scarification, $L N$ liquid nitrogen. T85_t10 $-85^{\circ} \mathrm{C}$ (air temperature) by $10 \mathrm{~min}, \mathrm{~T} 85 \_\mathrm{t} 20-85^{\circ} \mathrm{C}$ by
$20 \mathrm{~min}$, T90_t $10-90{ }^{\circ} \mathrm{C}$ by $10 \mathrm{~min}$, T90_t $20-90{ }^{\circ} \mathrm{C}$ by $20 \mathrm{~min}$, T95_t $10-95{ }^{\circ} \mathrm{C}$ by $10 \mathrm{~min}, \mathrm{~T} 95 \_\mathrm{t} 20-95^{\circ} \mathrm{C}$ by $20 \mathrm{~min}$. Bars are standard deviations (SD)
On the fifth day of the incubation, the germination of mechanically scarified seeds was still maintained a significantly higher germination compared to seeds treated with time-thermal methods. However, the differences among seeds of MS and LN variants were not significant. In the fifth day, the seeds of T85_t10, T90_t10, T95_t10 and T95_t20 variants still germinated to a significantly lower percentage compared to LN. However, there were no significant differences between the same time-temperature variants. A week after incubation mechanically scarified seeds germinated to a significantly higher percentage than scarified seeds in different time-thermal variants. Similarly like after the fifth day, no significant differences were observed between MS and LN variants. The seeds scarified artificially with liquid nitrogen, germinated to a significantly higher percentage than the seeds from all thermaltime variants. However, even after 7 days from incubation, mechanically scarified seeds had a lower cumulative germination than the LN seeds. On tenth day of the incubation, the inhibition of the dynamics in germination of scarified mechanically seeds has been found. No significant differences were observed between MS and time-thermal variants. However, a significant increase in the percentage of germination of seeds which were scarified in LN has been also observed comparing to all methods, including MS. For time-thermal methods, after 10 days from incubation significantly higher germination of seeds was only found for T85_t20 variant comparing to seeds of T95_t20 variant. At the end of the test, after 14 days, there were not found any significant differences between MS and LN variant and a time-thermal variants, except for T95_t10 and T95_t20 variants. Seeds scarified in T95_t10 and T95_t10 variants, germinated to a significantly lower percentage compared to MS and LN variants. Germination of seeds scarified in variant T95_t10 was also significantly lower compared to seeds of T85_t20 variant. However, T95_t20 variant had a lower germination than T85_t10, T85_t20, T90_t10 and T90_t20 variants.

On the third day of the incubation, significant differences were observed between the analysed populations (Fig. 3). The highest percentage germination was found in MTS population (47.1\%). The lowest percentage germinated seeds were found in SO $(31.6 \%)$. This trend was continued until the end of the incubation period. After 14 days of incubation, there was no significant differences observed between MTS and SSS populations, whose seeds germinated significantly better than the seeds from SO.

\section{Discussion}

The seeds of black locust are characterised by a hard seed coat that is impermeable to water and gases. Thus, for this species, the natural seed dormancy is entirely physical (i.e., seed hardness). Physical dormancy is characteristic for several families of plants, one of the largest of which is Fabaceae (Baskin and Baskin 2009). Physical dormancy increases the resistance to microbiological infection (Dalling et al. 2011), extends the vitality of the seeds (Mohamed-Yasseen et al. 1994) and is favourable for maintaining the soil seed bank (Shen-Miller et al. 1995). To break physical dormancy of seeds, the activity of microorganisms or high (fires) and low (frost) temperature cues are required (Dunn 1939; Cremer and Mount 1965; Dell 1980, Waldron et al. 2007). When the seed coat is damaged, water enters the seed and thereby initiates the process of germination. However, the proportion of seeds capable of germination without any treatment is typically 
Fig. 3 Germination dynamics of seeds with different provenances. MTS managed tree stand, SSS selected seed stand, $S O$ seed orchard. Bars are standard deviations

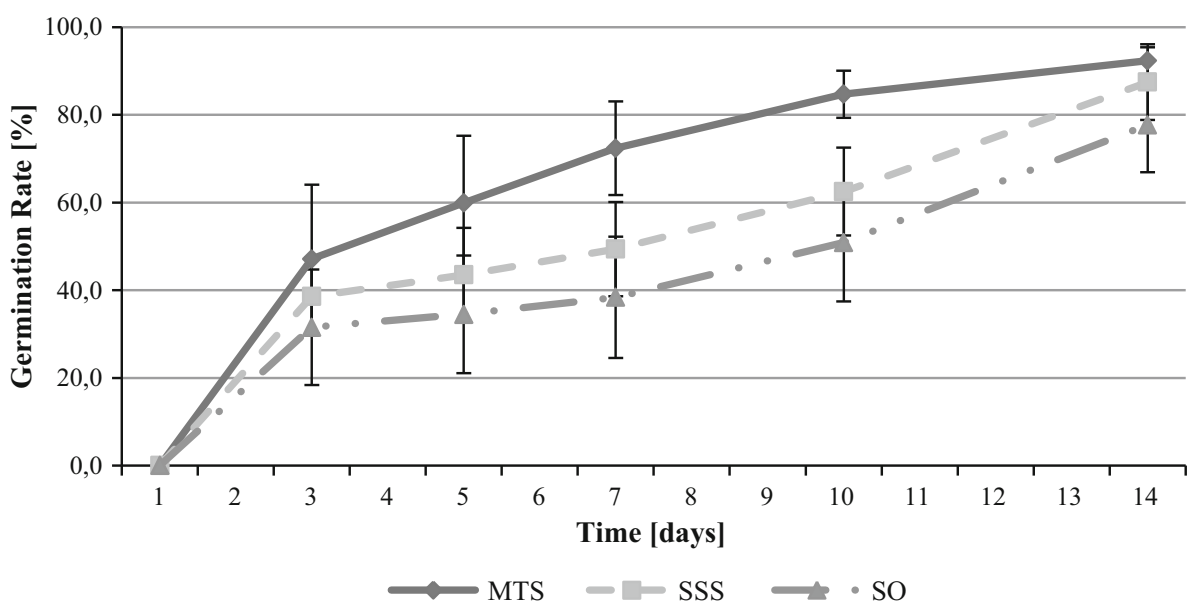

low, as demonstrated by the average level of $10.8 \%$ obtained in this study (Fig. 1).

The germination capacity of seeds not subjected to scarification during the current study was similar to that recorded by Mondoni et al. (2013) and Tylkowski and Grupa (2010). For economic purposes, scarification treatment is applied to seeds before sowing to increase the germination rate. Common scarification methods include treating seeds in water baths at temperatures that range from 60 up to $98{ }^{\circ} \mathrm{C}$ (Bärtels 1982; Terpiński 1984; Singh et al. 1991; Tylkowski and Grupa 2010), with sulphuric acid (Olson and Karrfalt 2008) or with methods that physically damage the seed coat (Khadduri and Harrington 2002; Zajączkowski 2007; Mondoni et al. 2013).

However, to date, the effectiveness of these methods has not always proved satisfactory. The application of temperatures that are too high may destroy seeds, whereas the use of concentrated sulphuric acid requires special equipment and protective measures. Singh et al. (1991) reported that the best alternative to the application of sulphuric acid is the submersion of seeds in boiling water, or mechanical scarification. In their study, burning openings in the seed coat using a heated needle was also applied. According to these authors, with the exception of submersion in sulphuric acid, the most effective method of scarification of black locust seeds is cutting or burning openings in the seed coat. However, because cutting and burning are very arduous methods, they are only applicable to laboratory conditions or for small-scale forest nurseries. Singh et al. (1991) suggested that the use of boiling water is more effective for those nurseries that operate at larger scales. Giuliani et al. (2015) reached similar conclusions in a study of the effects of pre-sowing treatment and temperature on the germination of seeds from various provenances of black locust from Tuscany. In that study, the best results were obtained after the mechanical incision of the seed coat. However, they reported that use of boiling water for 20 min significantly decreased the germination capacity.

Studying the efficiency of different scarification methods for the seeds of six different species in the family Fabaceae, Mondoni et al. (2013) reported that specialised scarifying instruments, scarifiers, were highly suitable.

Investigating different methods of scarification of black locust seeds of Polish provenances, Tylkowski and Grupa (2010) also concluded that mechanical methods are apparently the most effective. According to these authors, such methods are less risky because they are safer and reduce the losses caused by damage to seeds. Additionally, mechanical methods are less labour intensive than thermal and chemical methods. Tylkowski and Grupa (2010) obtained a germination capacity for black locust seeds after mechanical scarification in the range of $87.9-96.3 \%$, compared with the low germination rate of $40.1 \%$ with the use of thermal scarification (in water). Similar to the results of those authors, in the current study, the seeds from the SSS and SO were more affected by the scarification methods than were those in the MTS.

Without scarification, the seeds of black locust germinated to a very low level of approximately 10-20\% (Tylkowski and Grupa 2010, Mirzaei et al. 2013, Mondoni et al. 2013). Similarly, in our investigations, unscarified seeds germinated in the range of 5-12\%, regardless of their provenance (Fig. 3). This indicates black locust possess relatively constant amount of non-dormant seeds. On the Hokkaido island, when Masaka and Yamada (2009) examined the variability of germination capability of black locust trees, it was stated as well the existence of individual variability of this trait of seeds. Black locust is a species that produces dimorphic seeds regarding the thickness of the seed coat (Baskin and Baskin 2009), and in a single set of seeds, both "hard" and "soft" seeds can be identified. "Hard" seeds do not produce volatile compounds that 
allow rodents to find the location of the seeds, which is related to the evolutionary adaptation of this species to increase reproductive success (Paulsen et al. 2013). The sensitivity to time-temperature treatments was also most likely dependent on the thickness of the seed coat; therefore, coat thickness determined susceptibility to the high or low temperatures.

In our study, high and low temperatures and the temperature of liquid nitrogen were used to scarify the seeds of black locust. Dry heat is effective in breaking physical dormancy in seeds of a number of species, but the appropriate dry-heat treatment should be determined by experimentation to find the combination of temperature and duration of treatment that results in high germination percentage but not in death of the embryo (Baskin and Baskin 2009). In our study, the seeds were frozen at $-70^{\circ} \mathrm{C}$ and then placed in a temperature above $85^{\circ} \mathrm{C}$, which led to thermal shock, damage to the seed coat and an increase in the level of germination up to $95.0 \%$. The application of high air temperatures in the range from 85 to $90{ }^{\circ} \mathrm{C}$ for 10 and 20 min under controlled conditions obtained uniform germination and a high efficiency of sowing in the nursery. The germination evenly spread over time; it is very important for nursery production. It allows to schedule work at forest nursery and obtain a uniform seeding material.

The effect of high temperatures on breaking the physical dormancy of seeds was also studied inter alia by Mott et al. (1982), Thanos et al. (1992) and Chawan (1971). For most species, breaking seed dormancy requires a few minutes at a temperature of approximately $100{ }^{\circ} \mathrm{C}$. Narang and Bhardwaja (1974) and Brown and Booysen (1969) found that by drying seeds at high temperatures cracks formed in the layer of palisade strophiole in Tephrosia appolina and Acacia spp.; however, Cavanagh (1987) questioned whether the cracks caused by the effect of warm air were sufficiently deep for water to reach the embryos. According to Cavanagh (1987), water would penetrate by the strophiole and therefore improve germination.

The use of liquid nitrogen was a particularly noteworthy method because it was quick to apply (immersion for only $10 \mathrm{~s}$ ) and provided very good effects. Although the contact of seeds with liquid nitrogen is short, micro-damages occur to the seed coat, which allows water to penetrate into the interior of the seed, with minimal risk of damage to the embryo. Additionally, prolonging the duration for which seeds are immersed in liquid nitrogen does not improve the germination capacity (Eynard 1960; Brant et al. 1971). The disadvantages of using liquid nitrogen include the relatively high cost and the possibility of the phenomenon of seedlings with abnormal growth (Pritchard et al. 1988; Wiesner et al. 1994). In the opinion of authors, the use of liquid nitrogen for scarification of black locust beans does not require any special equipment. It is not as well very expensive treatment. Currently, it is possible to provide the liquid nitrogen directly to particular forest nursery and use it without keeping it for long.

When the effectiveness of methods for the scarification of black locust seeds is evaluated, the influence of seed origin is rarely considered (Tylkowski and Grupa 2010; Giuliani et al. 2015). In this study, significant differences were found among the germination capacities of seeds from the different provenances. It is, however, rather the feature of individual than characteristic for a specific population (Masaka and Yamada 2009).

The unexpected low germination capacity of seeds from the SO is also an unexplained result. The entire seed orchard consisted of only a few grafts, with only two clones of mother trees that possessed fruits. Therefore, the seeds examined did not fully represent the seeds from the seed orchard.

Moreover, insects pollinate black locust; however, the pollination pattern within a plantation is unknown, in addition to the intensity of flights of pollinators (honeybees). Therefore, based on the distribution of fruiting grafts, the inference is, with high probability, that selfpollination processes have been repeated, with the result that the seeds formed, in general, are incapable of germination (Yuan et al. 2014).

\section{Conclusions}

- Seeds not treated with scarification are characterised by much lower germination capacity.

- Average germination capacity can depend on the management of forest stands or their type of reproduction.

- Uniform germination of seeds was obtained by using liquid nitrogen for scarification.

- Scarification of black locust seeds at $95{ }^{\circ} \mathrm{C}$ for 10 or 20 min reduced the germination capacity.

- Thermal scarification of the seeds of black locust was most effective in the temperature range $85-90{ }^{\circ} \mathrm{C}$, with exposure times of 20 and $10 \mathrm{~min}$, respectively.

- Thermal methods and the use liquid nitrogen may provide alternatives to the labour intensive cutting of seeds and methods that require the use of specific equipment (e.g., soaking in sulphuric acid).

Acknowledgements Studies were conducted within the framework of the Project BLP-386, funded by the General Directorate of State Forests in Poland. The authors express their gratitude to Mrs. Ewa Aniśko, M.Sc. and Mrs. Hanna Lipińska for their assistance in conducting the tests of germination capacity, which were performed at the Seed Testing Station of the Forest Research Institute in Sękocin Stary. This research is linked to activities conducted within the COST FP1403 "NNEXT" network. 
Open Access This article is distributed under the terms of the Creative Commons Attribution 4.0 International License (http://crea tivecommons.org/licenses/by/4.0/), which permits unrestricted use, distribution, and reproduction in any medium, provided you give appropriate credit to the original author(s) and the source, provide a link to the Creative Commons license, and indicate if changes were made.

\section{References}

Bärtels A (1982) Rozmnażanie drzew i krzewów ozdobnych. PWRiL, Warszawa

Baskin CC (2003) Breaking physical dormancy in seeds-focusing on the lens. New Phytol 158:227-238

Baskin CC, Baskin JM (2009) Seeds-ecology, biogeography, and evolution of dormancy and germination. Academic Press, San Diego

Bewley JD (1997) Seed germination and dormancy. Plant Cell 9:1055-1066

Borkowska L (2004) Patterns of seedling recruitment in experimental gaps on mosaic vegetation of abandoned meadows. Acta Soc Bot Pol 73(4):343-350

Brant RE, McKee GW, Cleveland RW (1971) Effect of chemical and physical treatment on hard seed of penngift crownvetch. Crop Sci. doi:10.2135/cropsci1971.0011183X001100010001x

Brown NAC, Booysen PDV (1969) Seed coat impermeability in several Acacia species. Agroplantae 1:51-60

Cavanagh T (1987) Germination of hard-seeded species (order Fabales). In: Langkamp L (ed) Germination of Australian native plant seed. Inkata Press, Melbourne

Chapman AG (1936) Scarification of black locust seed to increase and hasten germination. J For 34:66-74

Chawan DD (1971) Role of high temperature pretreatment on seed germination of desert species of Sida (Malvaceae). Oecologia 6:343-349

Cierjacks A, Kowarik I, Joshi J, Hempel S, Ristow M, von der Lippe M, Weber E (2013) Biological flora of the British Isles: Robinia pseudoacacia. J Ecol 273:1-18. doi:10.1111/13652745.12162

Cremer KW, Mount AB (1965) Early stages of plant succession following the complete felling and burning of Eucalyptus regnans forest in the Florentine Valley, Tasmania. Aust J Bot 13:303-322

Cseresnyés I, Csontos P (2012) Soil seed bank of the invasive Robinia pseudoacacia in planted Pinus nigra stands. Acta Bot Croat 71(2):249-260

Dalling JW, Davis AS, Schutte BJ, Arnold AE (2011) Seed survival in soil: interacting effects of predation, dormancy and the soil microbial community. J Ecol 99:89-95

Danielewicz W, Wiatrowska B (2012) Motywy, okoliczności i środowiskowe konsekwencje wprowadzania obcych gatunków drzew i krzewów do lasów. Studia i Materiały CEPL 14(33/ 4):26-43

DeGomez T, Wagner MR (2001) Culture and use of black locust. Horttechnology 11:279-288

Dell B (1980) Structure and function of the strophiolar plug in seeds of Albizia lophanta. Am J Bot 67:556-563

Dunn LE (1939) Influence of low temperature treatments on the germination of seeds of sweet clover and smooth vetch. Agron J 31:687-694

Eynard I (1960) Effect of liquid $\mathrm{N}_{2}$ and $\mathrm{O}_{2}$ on the germination of hard seeds. Herb Abst 28:1027

Falińska K (2002) Przewodnik do badań biologii populacji roślin. PWN, Warszawa
Gazda A (2012) Stan badań nad obcymi gatunkami drzew w polskich lasach. Studia i Materiały CEPL w Rogowie 14(33/4):44-52

Giuliani C, Lazzaro L, Lippi MM, Calamassi R, Foggi B (2015) Temperature-related effects on the germination capacity of black locust (Robinia pseudoacacia L., Fabaceae) seeds. Folia Geobot 50:275-282. doi:10.1007/s12224-015-9244-x

Hanna PJ (1983) Anatomical features of the seed coat of Acacia kempeana (Mueller) which relate to increased germination rate induced by heat treatment. New Phytol 96:23-29

ISTA (2013) International rules for seed testing, 2013th edn. Intentional Seed Testing Association, Bassersdorf

Jackson MT, Strait RA (1987) Woody invaders resist fire, cutting, herbicides. Restor Manag Notes 5(2):86

Khadduri NY, Harrington JT (2002) Shaken. Not stirred-a percussion scarification technique. Native Plants J 3(1):65-66

Kowalewski M (2013) Wpływ obcych gatunków drzew na ekosystemy leśne. Post Tech Leś 121:30-35

Kraszkiewicz A (2013) Evaluation of the possibility of energy use black locust (Robinia pseudoacacia L.) dendromass acquired in forest stands growing on clay soils. J Cent Eur Agric 14(1):388-399

Lewak S (2002) Kiełkowanie nasion. In: Kopcewicz J, Lewak S (eds) Fizjologia roślin. PWN, Warszawa, pp 485-497

Littell RC, Milliken GA, Stroup WW, Wolfinger RD (1996) SAS system for mixed models. SAS Institute Inc., Cary

Masaka K, Yamada K (2009) Variation in germination character of Robinia pseudoacacia L. (Leguminosae) seeds at individual tree level. J For Res 14:167-177. doi:10.1007/s10310-009-0117-9

McKeever DG (1937) A new black locust seed treatment. J For 35:500-501

Mirzaei M, Moghadam ARL, Ardebili ZO (2013) The induction of seed germination using sulfuric acid, gibberellic acid and hot water in Robinia pseudoacacia L. Int Res J Appl Basic Sci 4(1):96-98

Mohamed-Yasseen Y, Barringer S, Splittstoesser W, Costanza S (1994) The role of seed coats in seed viability. Bot Rev 60:426-439

Mondoni A, Tazzari ER, Zubani L, Orsenigo S, Rossi G (2013) Percussion as an effective seed treatment for herbaceous legumes (Fabaceae): implications for habitat restoration and agriculture. Seed Sci Technol 41:175-187

Mott JJ, Cook SJ, Williams RJ (1982) Influence of short duration, high temperature seed treatment on the germination of some tropical and temperate legumes. Trop Grassl 16:50-55

Narang AK, Bhardwaja N (1974) Seed coat regulated germination in Tephrosia appolina DC. and its significance. Int J Ecol Environ Sci 1:47-51

Nikolaeva MG, Razumova MV, Gladkova VN (1985) Reference book on dormant seed germiantion. Nauka, Leningrad

Olson DF Jr, Karrfalt RP (2008) Robinia L. locust. In: Bonner F, Karrfalt RP (eds) The woody plant seed manual. Agriculture handbook, vol 727. USDA Forest Service, Washington

Pacyniak C (1981) Robinia akacjowa (Robinia pseudoacacia L.) w warunkach środowiska leśnego w Polsce. Roczniki Akademii Rolniczej w Poznaniu. Rozprawy Naukowe 111:85

Pacyniak C (2003) Robinia akacjowa (Robinia pseudoacacia L.) kontrowersyjny gatunek drzewa w Polsce? Przegląd Leśniczy $4: 8-9$

Paulsen TR, Colville L, Kranner I, Daws MI, Högstedt G, Vandvik V, Thompson K (2013) Physical dormancy in seeds: a game of hide and seek? New Phytol 198:496-503

Pritchard HW, Manger KR, Prendergast FG (1988) Changes in Trifolium arvense seed quality following alternating temperature treatment using liquid nitrogen. Ann Bot 62:1-11

Program zachowania leśnych zasobów genowych i hodowli selekcyjnej drzew leśnych w Polsce na lata 2011-2035, CILP 
Rédei K (2013) Black locust (Robinia pseudoacacia L.) growing in Hungary. ERTI, Sárvar

SAS Institute Inc (2013) SAS/STAT 9.4 user's guide. SAS Institute Inc, Cary

Shen-Miller J, Mudgett MB, Schopf JW, Clarke S, Berger R (1995) Exceptional seed longevity and robust growth: ancient Sacred Lotus from China. Am J Bot 82:1367-1380

Singh DP, Hooda MS, Bonner FT (1991) An evaluation of scarification methods for seeds of two leguminous trees. New For 5(2):139-145

Terpiński Z (1984) Szkółkarstwo ozdobne. PWRiL, Warszawa

Thanos CA, Georghiou K, Kadis C, Pantazi C (1992) Cistaceae: a plant family with hard seeds. Isr J Bot 41:251-263

Tylkowski T, Grupa R (2010) Skuteczność przedsiewnych metod skaryfikacji nasion robinii akacjowej. Sylwan 154(1):33-40

USDA Forest Service (1974) The seeds of woody plants in the United States. USDA forest service, agricultural handbooks, vol 450. U.S Govt. Printing Office, Washington

Waldron JD, Lafon CW, Coulson RN, Cairns DM, Tchakerian MD, Birt A, Klepzig KD (2007) Simulating the impacts of southern pine beetle and fire on the dynamics of xerophytic pine landscapes in the southern Appalachians. Appl Veg Sci 10:53-64

Węgorek T, Kraszkiewicz A (2005) Dynamika wzrostu robinii akacjowej (Robinia pseudoacacia L.) w zadrzewieniu śródpolnym na glebach lessowych. Acta Agrophysica 5(1):211-218
Wiesner LE, Laufmann JE, Stanwood PC, Wheeler LJ (1994) The effect of liquid nitrogen on alfalfa seed viability, emergence and broken cotyledons. J Seed Technol 18:1-6

Willis CG, Baskin CC, Baskin JM, Auld JR, Lawrence Venable D, Cavender-Bares J, Donohue K, Rubio de Casas R (2014) The evolution of seed dormancy: environmental cues, evolutionary hubs, and diversification of the seed plants. New Phytol 203:300-309. doi:10.1111/nph.12782

Wojda T, Klisz M, Jastrzębowski S, Mionskowski M, Szyp-Borowska I, Szczygieł K (2015) The geographical distribution of the black locust (Robinia pseudoacacia L.) in Poland, and its role on nonforest land. Pap Glob Chang 22:101-113. doi:10.1515/igbp2015-0018

Yuan C-Q, Sun Y-H, Li Y-F, Zhao K-Q, Hu R-Y, Li Y (2014) Selection occurs within linear fruit and during the early stages of reproduction in Robinia pseudoacacia. BMC Evol Biol 14:53

Zajączkowski K (2007) Robinia akacjowa jako roślina energetyczna. Wokół Energetyki 10(5):30-33

Zajączkowski K (2013) Plantacje drzew szybko rosnących. Hodowla Lasu, Tom. IV. PWRiL, Warszawa

Zajączkowski K, Wojda T (2012) Robinia akacjowa Robinia pseudoacacia L. w gospodarczej uprawie plantacyjnej. Studia i Materiały CEPL 14(33/4):130-135

Załęski A (2000) Zasady i metodyka oceny nasion w Lasach Państwowych (ed) CILP, Warszawa 